\title{
A citizen-based platform reveals the distribution of functional groups inside a large city from the Southern Hemisphere: e-Bird and the urban birds of Santiago (Central Chile)
}

Pablo Gutiérrez-Tapia ${ }^{1 *}$, M. Ignacio Azócar ${ }^{2}$ and Sergio A. Castro ${ }^{1,3}$

\begin{abstract}
Background: Current knowledge of urban bird ecology and biodiversity relies on evidence from cities of the Northern Hemisphere, while the Southern Hemisphere is underrepresented. Santiago is a large city from South America, located in central Chile, which is both a biodiversity hotspot and an Endemic Bird Area. This work is a synthesis, which aims to provide a diversity account for Santiago, and to describe the broad geographic distribution and bird functional patterns.

Methods: We synthesized a seven-year (2009-2016) bird register from the eBird database (21,865 georeferenced registers at Santiago) into a single avifaunal account, along with the observed number of individuals. We complemented these registers by using available literature about Santiago's avifauna (28 references). We investigated the proportion of native/ exotic, migrants/residents, conservation categories, and urban nesting status. We classified Santiago's birds into seven trophic guilds. We plotted species richness and number of individuals for each functional group, by interpolating trough the Inverse Distance Weighted Method.

Results: We found that Santiago's avifauna (46 species) is composed mainly by native (41), resident (38), non-threatened species (46) that breed inside the city (31). Some functional groups inhabit a large portion of Santiago's urban surface, reaching high values of richness and abundance. Among these groups are the native, urban-nesters and resident species; even though exotics possess low species richness (5), they are abundant and inhabit the complete urban surface of the city.

The dominant trophic guilds are omnivorous (11) and granivorous (10). Insectivorous are the third most abundant trophic guild, and show the highest species richness (13).

Conclusion: The functional groups with lower species richness are less abundant and display reduced and patchy distributions in Santiago. This is probably because of the low availability of suitable habitats and/or restricted food supply (migrants, carnivorous, nectarivorous, frugivorous, herbivorous and piscivorous). The high insectivorous richness reported in Santiago, along with similar patterns reported in several cities in the Neotropics, provides evidence to postulate a pattern of high species richness of this guild in cities across this biogeographic realm.
\end{abstract}

Keywords: Biodiversity hotspot, Central Chile, Endemic bird area, South America, Trophic guilds, Urban biodiversity, Urban birds, Urban ecology

\footnotetext{
* Correspondence: pablo.gutierrez.t@usach.cl

${ }^{1}$ Laboratorio de Ecología y Biodiversidad, Departamento de Biología,

Universidad de Santiago de Chile, Casilla 40, Correo 33, Santiago. Av. Lib. B.

O'Higgins, 3363 Santiago, Chile

Full list of author information is available at the end of the article
} 


\section{Background}

Urbanization is one of the greatest threats to biodiversity at the global scale $[1,2]$. Birds comprise a highly conspicuous group among the vertebrates that are able to live in cities. Therefore, they have been one of the most intensively studied taxa in urban environments [3-5]. Nevertheless, current knowledge of urban bird diversity relies in evidence from cities from the Northern Hemisphere, located mainly in North America and Europe [3, 6, 7]. On the other hand, there are few studies in other continents such as Africa, Australia, and South America [8, 9]. This unbalance in geographic coverage is emphasized when bearing in mind that several biogeographic regions, other than the Nearctic and the Palearctic, and more than a half of the geographical units which harbor the entire breeding range of two or more restricted-range bird species (Endemic Bird Areas of the world, EBAs) are located in the Southern Hemisphere [10, 11]. For that reason, we believe that the ecological configurations of urban bird biodiversity, which could emerge when urbanization interacts with different regional bird species pools, other than the Northern Hemisphere, are potentially being missed. Therefore, studies of urban avifauna at these understudied continents are necessary, because they could enlighten the general biodiversity patterns of urban avifauna of the world, with an emphasis on the species composition of the avifauna in underrepresented continents.

Bird species richness in cities varies across a broad range, both within and between biogeographic realms. At the global scale, the median urban bird richness per city is near 100 species, being the Indo-Malayan and Afrotropical realms with the highest median species richness (median richness above 200 species). This is followed by the Neotropics (median richness above 100 species) [6]. On the other hand, the Palearctic, Nearctic and Australasia are the realms with the lowest urban bird richness scales [6]. As a general trend, core urban avifauna is characterized by a decrease in species richness compared to surrounding peri-urban areas [4]. A similar pattern is observed within cities, where species richness decreases from the peri- and suburban areas, to the downtown areas [12]. The urban - dwelling birds are usually a combination of native and exotic species [7]. In spite of some examples where exotics outnumber native species in a city [13], the general pattern is that urban bird fauna is composed by a higher amount of native and a lower amount of exotic species $[4,14,15]$. In general, there is an average of $3 \%$ of exotic species per city [6], and an increasing proportion of exotic species towards the downtown areas [5]. These findings have suggested that urban bird fauna may depend largely on the native species pool; while evidence indicates that this is true for peri- and suburban areas, it does not necessarily hold for the downtown areas $[4,16,17]$.
The classification of bird species into different trophic guilds is another attribute of interest in the study of urban fauna. Urban environments tend to increase the representation of species with generalist habits. In fact, the omnivorous guild frequently displays the most abundant bird species numbers in urban centres, usually being the dominant trophic guild in the most intensively urbanized areas $[7,12,18,19]$. Alternatively, granivorous have been reported as the dominant guild in highly urbanized areas in some cities $[14,20]$, although the dominance of omnivorous is the most frequent pattern. From the opposing point of view, carnivorous $[3,14]$ and insectivorous birds [3, 12, $15,20-22]$ are considered at a disadvantage in highly urbanized areas, declining in both species richness and abundance. It is unclear if urban environments influence some other particular trophic group [4], because evidence shows that urban gradients in different cities may exert different effects in other trophic guilds [9, 15, 23-26]. On the other hand, nesting patterns in breeding urban birds show two clear general trends: The most successful urban dwellers are characterized by i) showing cavity nesting behavior [3] and ii) building nests located a few meters above the ground or in the canopy [4, 27]. Additionally, as an interpretation of the most recent review of urban ornithology [7], it is possible to conclude that other interesting traits of world urban avifauna, such as the resident/migrant fraction and the species conservation status, are surprisingly understudied.

\section{Birds in Santiago}

The city of Santiago $\left(33.45^{\circ} \mathrm{S}-70.05^{\circ} \mathrm{W} ; 558\right.$ m.a.s.l; $619 \mathrm{~km}^{2}$ ), is the largest and most populated urban center in Chile $[28,29]$. It is located within a Mediterranean - type ecoregion at the globally significant biodiversity hotspot of Central Chile [30], which geographically coincides with the 'Central Chile' EBA [31]. It is the larger and most intensively urbanized centre in which Chilean bird diversity have been studied. There have been several efforts to partially characterize the urban bird ecology and diversity in Santiago [32-37], but they show high heterogeneity in terms of what should be considered an 'urban bird species account'.

Given that Santiago is a large and densely populated urban hub, the city emerges as an interesting research model for the study of South American urban bird biodiversity. The city of Santiago is experiencing an advanced urbanization process in an area with an increasing risk of habitat loss in a unique biogeographic scenario. In addition, it is located in an underrepresented hemisphere in terms of the knowledge of urban birds. For these reasons, we need an ecological and biogeographic characterization of Santiago's avifauna. This work aims to compare bird diversity and functional patterns of this large urban center in southern South America with expected trends, based mainly on evidence from 
the Northern Hemisphere. We used georeferenced data from the citizen-based bird database eBird.org [38] to characterize the complete avifauna of the city, exploring the coarse distribution of species richness and total abundance for the different functional groups. Additionally, we assessed if some guilds are characterized by particularly high abundance or species richness, and what is the native/exotic species ratio for the whole assemblage, and by each trophic guild. To complement the effort, we determined what is the proportion of urban nesting species shared by each trophic guild, and what is the conservation status reported for each bird species.

We hope that this will be an initial information framework for further research in urban bird biodiversity, in a particularly interesting urban and biogeographic setup, and in a globally underrepresented region in terms of urban bird biodiversity knowledge.

\section{Methods}

\section{Study area}

The city of Santiago $\left(33.45^{\circ} \mathrm{S}-70.05^{\circ} \mathrm{W} ; 558\right.$ m.a.s.l. $619 \mathrm{~km}^{2}$ ) is located inside the administrative region called "Región Metropolitana de Chile" (Fig. 1). This region concentrates $40.1 \%$ of the national population, sharing the highest human population density of the country (393,5 people per $\mathrm{km}^{2}$, Instituto Nacional de Estadísticas [29]). This fact positions Santiago as one of the 42 urban agglomerations in the world, which sustain more than $40 \%$ of the population of their respective countries. In addition, it lies inside the "large city" category (5-10 million people), along with other cities such as Madrid (Spain) and Singapore (Singapore). That category is expected to grow, encompassing 163 urban centres housing more than 400 million people by 2030 [39].

Our analyses are restricted within the urban perimeter of the city (approximately $619 \mathrm{~km}^{2}$ ). This research considered Santiago's urban perimeter according to the urban areas of Chile database, available at the "Integrated System of Territorial Information" of the National Library of Congress of Chile [40]. Santiago lies inside the biogeographic sub-region of central Chile [41], which roughly overlaps with the central Chile hotspot of biodiversity [30] and the central Chile Endemic Bird Area EBA [42]. EBAs are a system of geographic areas around the world considered relevant for bird conservation, because they harbor the entire breeding range of two or more restricted-range bird species, defined as species whose full breeding range is less than $50,000 \mathrm{~km}^{2}$ [11].

Use of the citizen-based platform eBird for the Santiago's avifauna characterization: Species composition, biogeographic origin and ecological features

Santiago's avifauna (Table 1) was determined by using bird registers available on the eBird database for
Santiago, Región Metropolitana de Chile [38, 43]. The Ornithology Lab of Cornell University manages the eBird database. Volunteer citizens around the world provide registers on this database; a two - step process confirms each register, which involves 1) automatic filters, and 2) local expert validation. This data validation process has positioned eBird as a reliable source of ornithological data, which has resulted in a growing number of publications based on the eBird database [44-52]. Despite this rigorous validation process, there are intrinsic characteristics in this kind of datasets, built by the contributions of non-professional observers which don't follow any sampling design. For instance, differences in the registers density in space, and differences in sampling effort among different localities and/or groups o taxa. In this work, differences of registers density were boarded in a geographically explicit interpolation approach, while the effect of different sample effort among groups of taxa was controlled by using rarefaction curves (more details in the analyses section). Finally, we consider that the anecdotical possibility of duplicates for a single observation is one of the trade-offs of this kind of dataset, in contrast with the availability of thousands of registers, in a temporal and geographic framework which are prohibitive in traditional sampling approaches.

The search criteria implemented for the eBird database were: i) all registers from Santiago (Chile, Region Metropolitana) between the years of 2009 to 2016 were considered; ii) Registers outside the urban perimeter of Santiago [40] were excluded. This criterion excludes registers in localities within the Andean Range (Fig. 1), which despite being inside the administrative boundaries of the city, fall outside Santiago's urban perimeter and are highly intermingled with the purely Andean ecosystems. Therefore, we did not consider its biota as urban. This criterion also required to exclude registers from the locality named 'Cerro San Cristobal', because this hill is a continuous projection of the Andean mountain range, although it lies within the urban core of Santiago (Fig. 1). We also excluded species with less than 10-point registers inside the urban perimeter of Santiago from 2009 to 2016, because species bellow that threshold were considered anecdotal sightings rather than true urban dwellers. We also excluded aquatic bird species kept by humans in artificial water reservoirs at urban parks. The resulting avifaunal account was compared to the bird species reported in several partial descriptions of Santiago's avifauna [32-37, 53], to check if some species reported in the city were being missed in the eBird database (except for the species already excluded by the former criteria). We detected no discordance. After these steps, we obtained a consensual list for the avifauna of Santiago. 


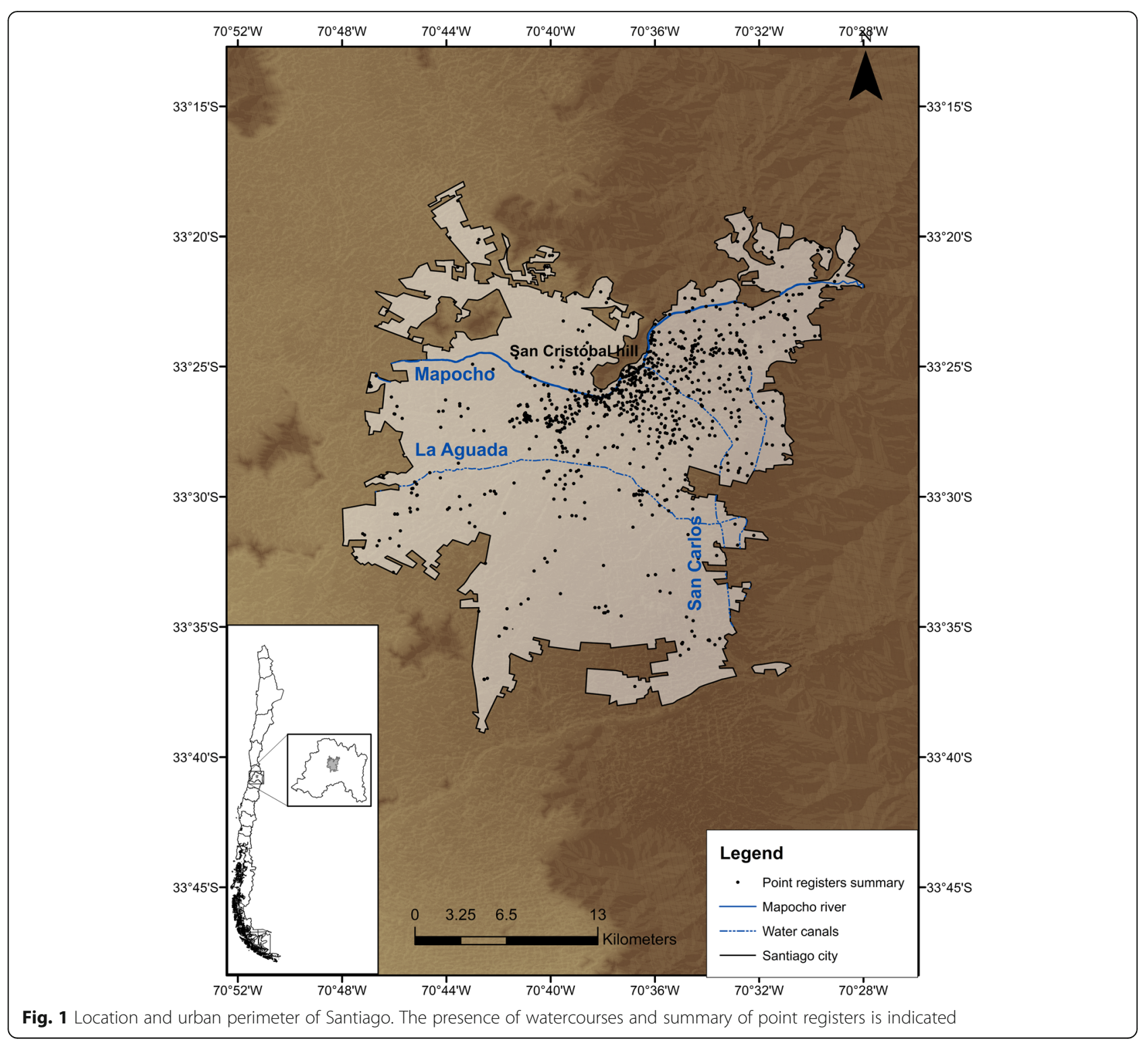

\section{Ecological features of the birds of Santiago: Functional groups}

Systematic position and scientific nomenclature for each species were assigned according to the 'South American Classification Committee' Birds Checklist [54]. Common names and resident /migratory status were given according to $[34,55]$. We defined residents as species that live year-round in a particular area, while migratory as those which display regular movements of all or part of their populations, to or from an area during part of the year, as a consequence of breeding periods or feeding area availability [56]. Santiago's birds were classified by biogeographic origin as native or exotic, by following the list of bird species from Chile which are distributed outside their native distribution range [57], and are able to sustain populations without direct human intervention (naturalized sensu [58]). We set the conservation status according to the International Union for the Conservation of Nature (IUCN) [59]. Information about nesting for each species is scarce, and was therefore compiled from several sources and personal observations [33, 34, 36, 43, 53].

We classified birds into four nesting categories and those with no conclusive information:

1. Confirmed urban nester (those with evidence of nests built inside the urban area).

2. Non - urban nester (species in which nest construction inside the urban perimeter have been discarded).

3. Probable urban nester (those which are thought to be urban nesters, but without any conclusive information). 
Table 1 Taxonomic classification of the bird species of Santiago

\begin{tabular}{|c|c|c|c|c|c|c|c|c|}
\hline Order & Family & Scientific name & $\begin{array}{l}\text { Trophic } \\
\text { guild }\end{array}$ & $\begin{array}{l}\text { Migratory/ } \\
\text { Resident }\end{array}$ & $\begin{array}{l}\text { Urban } \\
\text { nesting }\end{array}$ & $\begin{array}{l}\text { English common } \\
\text { name }\end{array}$ & $\begin{array}{l}\text { Spanish } \\
\text { common name }\end{array}$ & $\begin{array}{l}\text { Conservation } \\
\text { status IUCN }\end{array}$ \\
\hline \multirow[t]{4}{*}{ Accipitriformes } & \multirow[t]{4}{*}{ Accipitridae } & Elanus leucurus & $C$ & $\mathrm{R}$ & $\begin{array}{l}\text { Without } \\
\text { information }\end{array}$ & White-tailed Kite & Bailarín & LC \\
\hline & & $\begin{array}{l}\text { Geranoaetus } \\
\text { melanoleucus }\end{array}$ & C & $\mathrm{R}$ & Yes & $\begin{array}{l}\text { Black-chested } \\
\text { Buzzard-Eagle }\end{array}$ & Aguila & LC \\
\hline & & $\begin{array}{l}\text { Geranoaetus } \\
\text { polyosoma }\end{array}$ & C & $\mathrm{R}$ & $\begin{array}{l}\text { Without } \\
\text { information }\end{array}$ & Variable hawk & Aguilucho & LC \\
\hline & & $\begin{array}{l}\text { Parabuteo } \\
\text { unicinctus }\end{array}$ & C & $R$ & $\begin{array}{l}\text { Without } \\
\text { information }\end{array}$ & Harris's hawk & Peuco & LC \\
\hline Apodiformes & Trochilidae & $\begin{array}{l}\text { Sephanoides } \\
\text { sephaniodes }\end{array}$ & $\mathrm{N}$ & M & No & $\begin{array}{l}\text { Green-backed } \\
\text { firecrown }\end{array}$ & Picaflor chico & LC \\
\hline \multirow[t]{3}{*}{ Charadriiformes } & Charadriidae & Vanellus chilensis & । & $\mathrm{R}$ & Yes & Southern lapwing & Queltehue & LC \\
\hline & \multirow[t]{2}{*}{ Laridae } & Larus dominicanus & $\mathrm{O}$ & $\mathrm{R}$ & No & Kelp gull & $\begin{array}{l}\text { Gaviota } \\
\text { dominicana }\end{array}$ & LC \\
\hline & & $\begin{array}{l}\text { Leucophaeus } \\
\text { pipixcan }\end{array}$ & $\mathrm{O}$ & M & No & Franklin's gull & $\begin{array}{l}\text { Gaviota de } \\
\text { Franklin }\end{array}$ & LC \\
\hline \multirow[t]{4}{*}{ Columbiformes } & \multirow[t]{4}{*}{ Columbidae } & Columba livia ${ }^{a}$ & $\mathrm{O}$ & $\mathrm{R}$ & Yes & Rock dove & Paloma & LC \\
\hline & & Columbina picui & G & $\mathrm{R}$ & Yes & Picui ground-dove & Tortolita cuyana & LC \\
\hline & & $\begin{array}{l}\text { Patagioenas } \\
\text { araucana }\end{array}$ & $F$ & M & $\begin{array}{l}\text { Without } \\
\text { information }\end{array}$ & Chilean pigeon & Torcaza & LC \\
\hline & & $\begin{array}{l}\text { Zenaida } \\
\text { auriculata }\end{array}$ & G & $\mathrm{R}$ & Yes & Eared dove & Tórtola & LC \\
\hline \multirow[t]{3}{*}{ Falconiformes } & \multirow[t]{3}{*}{ Falconidae } & Milvago chimango & O & $\mathrm{R}$ & Yes & Chimango caracara & Tiuque & LC \\
\hline & & Falco sparverius & C & $\mathrm{R}$ & Yes & American kestrel & Cernícalo & LC \\
\hline & & Falco peregrinus & C & $\mathrm{R}$ & Possibly & Peregrine falcon & Halcón peregrino & LC \\
\hline Galliformes & Odontophoridae & $\begin{array}{l}\text { Callipepla } \\
\text { californica }^{\text {a }}\end{array}$ & G & R & Yes & California quail & Codorniz & LC \\
\hline \multirow[t]{14}{*}{ Passeriformes } & Cotingidae & Phytotoma rara & $\mathrm{H}$ & $\mathrm{R}$ & Yes & $\begin{array}{l}\text { Rufous-tailed } \\
\text { plantcutter }\end{array}$ & Rara & LC \\
\hline & Emberizidae & $\begin{array}{l}\text { Zonotrichia } \\
\text { capensis }\end{array}$ & G & $\mathrm{R}$ & Yes & $\begin{array}{l}\text { Rufous-collared } \\
\text { sparrow }\end{array}$ & Chincol & LC \\
\hline & Fringillidae & Spinus barbatus & G & $R$ & Yes & Black-chinned siskin & Jilguero & LC \\
\hline & \multirow[t]{3}{*}{ Furnariidae } & $\begin{array}{l}\text { Aphrastura } \\
\text { spinicauda }\end{array}$ & I & $\mathrm{R}$ & Yes & $\begin{array}{l}\text { Thorn-tailed } \\
\text { rayadito }\end{array}$ & Rayadito & LC \\
\hline & & $\begin{array}{l}\text { Leptasthenura } \\
\text { aegithaloides }\end{array}$ & । & $\mathrm{R}$ & Yes & $\begin{array}{l}\text { Plain-mantledtit- } \\
\text { spinetail }\end{array}$ & Tijeral & LC \\
\hline & & $\begin{array}{l}\text { Upucerthia } \\
\text { saturatior }\end{array}$ & । & M & No & $\begin{array}{l}\text { Patagonian forest } \\
\text { earthcreeper }\end{array}$ & $\begin{array}{l}\text { Bandurrilla de los } \\
\text { bosques }\end{array}$ & NE \\
\hline & \multirow[t]{2}{*}{ Hirundinidae } & $\begin{array}{l}\text { Pygochelidon } \\
\text { cyanoleuca }\end{array}$ & । & M & Possibly & $\begin{array}{l}\text { Blue-and-white } \\
\text { swallow }\end{array}$ & $\begin{array}{l}\text { Golondrina de } \\
\text { dorso negro }\end{array}$ & LC \\
\hline & & $\begin{array}{l}\text { Tachycineta } \\
\text { leucopyga }\end{array}$ & । & $\mathrm{R}$ & Yes & Chilean swallow & $\begin{array}{l}\text { Golondrina } \\
\text { chilena }\end{array}$ & LC \\
\hline & \multirow[t]{4}{*}{ Icteridae } & Agelasticus thilius & । & $\mathrm{R}$ & Possibly & $\begin{array}{l}\text { Yellow-winged } \\
\text { blackbird }\end{array}$ & Trile & LC \\
\hline & & Curaeus curaeus & O & $\mathrm{R}$ & Yes & Austral blackbird & Tordo & LC \\
\hline & & $\begin{array}{l}\text { Molothrus } \\
\text { bonariensis }{ }^{\text {a }}\end{array}$ & O & $\mathrm{R}$ & Yes & Shiny cowbird & Mirlo & LC \\
\hline & & Sturnella loyca & $\mathrm{O}$ & $\mathrm{R}$ & Yes & $\begin{array}{l}\text { Long-tailed } \\
\text { meadowlark }\end{array}$ & Loica & LC \\
\hline & Mimidae & Mimus thenca & O & $\mathrm{R}$ & Yes & $\begin{array}{l}\text { Chilean } \\
\text { mockingbird }\end{array}$ & Tenca & LC \\
\hline & Passeridae & & 0 & $\mathrm{R}$ & Yes & House sparrow & Gorrión & LC \\
\hline
\end{tabular}


Table 1 Taxonomic classification of the bird species of Santiago (Continued)

\begin{tabular}{|c|c|c|c|c|c|c|c|c|}
\hline Order & Family & Scientific name & $\begin{array}{l}\text { Trophic } \\
\text { guild }\end{array}$ & $\begin{array}{l}\text { Migratory/ } \\
\text { Resident }\end{array}$ & $\begin{array}{l}\text { Urban } \\
\text { nesting }\end{array}$ & $\begin{array}{l}\text { English common } \\
\text { name }\end{array}$ & $\begin{array}{l}\text { Spanish } \\
\text { common name }\end{array}$ & $\begin{array}{l}\text { Conservation } \\
\text { status IUCN }\end{array}$ \\
\hline & & $\begin{array}{l}\text { Passer } \\
\text { domesticus a }^{\text {a }}\end{array}$ & & & & & & \\
\hline & Thraupidae & Diuca diuca & G & $\mathrm{R}$ & Yes & $\begin{array}{l}\text { Common } \\
\text { diuca-finch }\end{array}$ & Diuca & LC \\
\hline & & Phrygilus fruticeti & G & $\mathrm{R}$ & Yes & $\begin{array}{l}\text { Mourning } \\
\text { sierra-finch }\end{array}$ & Yal & LC \\
\hline & & Phrygilus gayi & G & M & $\begin{array}{l}\text { Without } \\
\text { information }\end{array}$ & $\begin{array}{l}\text { Gray-hooded } \\
\text { sierra-finch }\end{array}$ & $\begin{array}{l}\text { Cometocino } \\
\text { de gay }\end{array}$ & LC \\
\hline & & Sicalis luteola & G & R & Yes & $\begin{array}{l}\text { Grassland } \\
\text { yellow-finch }\end{array}$ & Chirihue & LC \\
\hline & Troglodytidae & $\begin{array}{l}\text { Troglodytes } \\
\text { aedon }\end{array}$ & I & R & Yes & House wren & Chercán & LC \\
\hline & Turdidae & Turdus falcklandii & $\mathrm{O}$ & $\mathrm{R}$ & Yes & Austral thrush & Zorzal & LC \\
\hline & Tyrannidae & Anairetes parulus & । & $\mathrm{R}$ & Yes & Tufted tit-tyrant & Cachudito & LC \\
\hline & & $\begin{array}{l}\text { Colorhamphus } \\
\text { parvirostris }\end{array}$ & I & M & No & Patagonian tyrant & Viudita & LC \\
\hline & & Elaenia albiceps & $\mathrm{O}$ & M & Yes & $\begin{array}{l}\text { White-crested } \\
\text { elaenia }\end{array}$ & Fío-fío & LC \\
\hline & & $\begin{array}{l}\text { Muscisaxicola } \\
\text { maclovianus }\end{array}$ & I & M & No & $\begin{array}{l}\text { Dark-faced } \\
\text { ground-tyrant }\end{array}$ & $\begin{array}{l}\text { Dormilona } \\
\text { tontita }\end{array}$ & LC \\
\hline & & Xolmis pyrope & । & $\mathrm{R}$ & $\begin{array}{l}\text { Without } \\
\text { information }\end{array}$ & Fire-eyed diucon & Diucón & LC \\
\hline Piciformes & Picidae & $\begin{array}{l}\text { Veniliornis } \\
\text { lignarius }\end{array}$ & I & $\mathrm{R}$ & Yes & $\begin{array}{l}\text { Striped } \\
\text { woodpecker }\end{array}$ & Carpinterito & LC \\
\hline Psittaciformes & Psittacidae & $\begin{array}{l}\text { Myiopsitta } \\
\text { monachus }^{\mathrm{a}}\end{array}$ & G & $\mathrm{R}$ & Yes & Monk parakeet & $\begin{array}{l}\text { Cotorra } \\
\text { argentina }\end{array}$ & LC \\
\hline \multirow[t]{2}{*}{ Strigiformes } & Strigidae & Glaucidium nana & C & $\mathrm{R}$ & Yes & Austral pygmy-owl & Chuncho & LC \\
\hline & Tytonidae & Tyto alba & C & $R$ & Yes & Barn owl & Lechuza & LC \\
\hline Suliformes & Phalacrocoracidae & $\begin{array}{l}\text { Phalacrocorax } \\
\text { brasilianus }\end{array}$ & $P$ & $\mathrm{R}$ & No & $\begin{array}{l}\text { Neotropic } \\
\text { cormorant }\end{array}$ & Yeco & LC \\
\hline
\end{tabular}

Trophic guild (Trophic guild classification: I Insectivorous, $O$ Omnivorous, $G$ Granivorous, $C$ Carnivorous, $F$ Frugivorous, $H$ Herbivorous, $N$ Nectarivorous and $P$ Piscivorous), $M$ migratory or $R$ resident status, urban nesting status and IUCN conservation status ( $L C$ least concern, $N E$ not evaluated) are included for each specie. Scientific names marked with ${ }^{\text {a }}$ are exotic species

We also included those with "no information" (Those birds in which the actual presence or absence of nests inside the urban perimeter is unknown).

Additional information regard nesting sites is provided in Additional file 1, together with additional references about trophic habits, nesting categories, migrant or resident status, distribution and biogeographic origin. Finally, species were classified into trophic guilds; we followed the guild categorization established for bird assemblages of North and South America [60].

Trophic guild categories considered in Santiago were:

1. Carnivorous $(\mathrm{C})$, eaters of vertebrates;

2. Granivorous $(\mathrm{G})$, eaters of seeds, (including nuts and seeds inside cones);

3. Frugivorous (F), eaters of fleshy fruits;
4. Herbivorous $(\mathrm{H})$, eaters of leaves or buds;

5. Insectivorous (I), eaters of arthropods;

6. Nectarivorous $(\mathrm{N})$, eaters of nectar and pollen;

7. Piscivorous $(\mathrm{P})$, primarily fish eaters; and

8. Omnivorous $(\mathrm{O})$, exploiters of more than one of the former trophic categories.

We synthesized the above information in a single database (Table 1 and Additional file 1).

\section{Analyses}

We used this data to describe the native/exotic ratio, migratory/resident ratio, the proportion of species in different conservation status, and nesting categories for the total urban bird assemblage. Additionally, we evaluated 
the number of native/exotic, resident/migratory, and nesting status by each trophic guild.

Georeferenced eBird registers from Santiago were classified into the previously defined functional groups (trophic guilds, native/exotic, migratory/resident, urban nester/ not-urban nester) to evaluate the species richness and number of individuals ("number of observations" field on eBird database) at each point register. We conducted this calculation considering the urban species altogether and according to the formerly described functional groups classification. Those point values (species richness and number of individuals) were interpolated through the inverse distance weighted method (IDW) implemented in ArcGIS desktop 10.3 [61], and plotted over the urban surface of Santiago. IDW is an interpolation method which assumes that closer points are more similar to each other than distant ones; it also considers the overall spatial composition between measured points in order to interpolate values [62-64] . This method has been considered advantageous as compared to other interpolation alternatives, for applications to bird richness and abundance data, because it restricts the interpolated values within the boundaries of observed minimum and maximum values [65]. This method is particularly suitable to visualize the eBird data set, because it can control the distance of influence exerted by a point register (power) as well as the number of point registers which are permitted to influence a particular point in the interpolation (neighbourhood). For IDW interpolation, values for parameters of power (p) and neighbourhood $(\mathrm{N})$ where $p=2$ and $N=4$, according to [64]. We selected the IDW visualization strategy to obtain a rapid diagnosis about the coarse distribution of functional groups in a large urban surface, based on eBird's massive amount of data for the complete avifauna of Santiago. We considered our data as a good proxy of diversity, but not as an accurate estimation of a bird's relative abundance. Therefore, we compared the observed species richness and rough number of individuals by each functional group in space, in an IDW context. The reliability of the observed species richness in functional groups with different sample sizes was evaluated through rarefaction curves, calculated using the "vegan" package in $\mathrm{R}[66]$.

\section{Results}

\section{Santiago's avifauna composition}

The eBird data from central Chile holds 210,805 records inside the administrative region called "Región Metropolitana de Santiago". About 21,865 of these registers are located inside the urban perimeter of Santiago. After applying our criteria to classify birds as urban dwellers, we concluded that Santiago hosts an assemblage of 46 urban bird species, representing 11 orders, 24 families and 43 genera (Table 1). These species are represented by a total of 20,962-point registers and 120,385 observed individuals. We excluded most aquatic birds because they were reported as being in water masses artificially available in urban parks; only three aquatic species were considered urban because they are frequently registered at the Mapocho River (Fig. 1), the main watercourse in Santiago, and other non-aquatic localities. These were the Kelp (Larus dominicanus) and Franklin's gulls (Leucophaeus pipixcan).

Passeriformes is the order with the highest species richness in the city, with 25 species (54\% of the total species richness). At the family level, the highest species richness occurs within five families, which altogether represent $47 \%$ of the total species richness. The family with the highest species richness in Santiago is Tyrannidae (Passeriformes), represented by five species (10.9\% of the total species richness). After Tyrannidae, Accipitridae (Accipitriformes), Columbidae (Columbiformes), Icteridae (Passeriformes), and Thraupidae (Passeriformes) are represented by four species each $(8.7 \%$ of the total species richness). Most families (15) are monospecific in Santiago. Almost all genera are monospecific at the city, except for Falco (Falconiformes), Geranoaetus (Accipitriformes) and Phrygillus (Passeriformes), each of them represented by two species.

\section{Functional groups: Origin, residence, nesting, conservation status and trophic guilds}

Most urban bird species in Santiago are native (89\%), resident (83\%) and urban nesters (67\%) (Fig. 2a-c). Almost all species are classified by the IUCN as 'Least concern (LC)' with the only exception of the Patagonian Forest Earthcreeper (Upucertia saturiator), which has not yet been evaluated (NE) (Table 1).

Santiago's urban bird assemblage is composed of eight observed trophic guilds. However, $92 \%$ of the species are distributed into just four guilds (Fig. 2d): Insectivorous comprise the guild with the highest species richness (13 species, $28 \%$ of the total richness), followed by omnivorous (11 species, $24 \%$ of the total richness), granivorous (10 species, 22\% of the total richness), and carnivorous (eight species, $18 \%$ of the total richness). In contrast, frugivorous, herbivorous, nectarivorous, and piscivorous are monospecific guilds in Santiago (Table 1, Fig. 2d).

Among the five exotic bird species of Santiago, two are classified as granivorous (The California Quail (Callipepla californica) and the Monk Parakeet (Myiopsitta monachus), and three as omnivorous (The Rock Dove - Columba livia), the Shiny Cowbird (Molothrus bonariensis) and the House Sparrow (Passer domesticus) (Table 1, Fig. 3a). From the eight migratory species registered in the city, four species are classified as insectivorous. These are the Patagonian Tyrant 

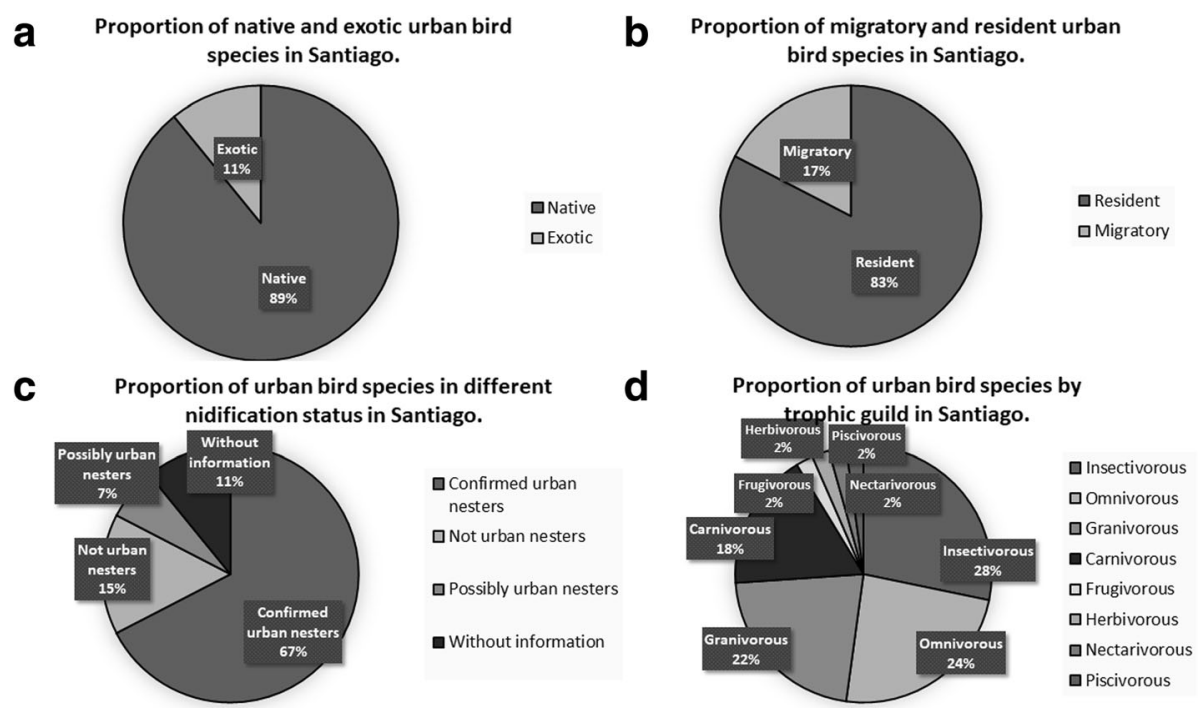

Fig. 2 Classification of the "urban bird species pool" of Santiago. Proportion of (a) native and exotic species (b) migratory and resident species (c) nesting status (confirmed urban nester, not urban nester, possibly urban nester or without information) (d) species in different trophic guilds

(Colorhamphus parvirostris), the Dark-Faced Groundtyrant (Muscisaxicola maclovianus), the Blue-and-white Swallow (Pygochelidon cyanoleuca) and the Patagonian Forest Earthcreeper (Upucerthia saturatior). We found two migratory omnivorous (White-crested Elaenia (Elaenia albiceps) and Franklin's Gull (Leucophaeus pipixcan). There is at least one migratory granivorous (Gray-Hooded Sierra-finch (Phrygilus gayi), and one nectarivorous (Green-backed Firecrown, (Sephanoides sephaniodes) (Table 1, Fig. 3b).
Even though insectivorous and carnivorous are among the guilds with the highest species richness in Santiago, only seven and five species are, respectively, confirmed urban nesters within these guilds (Fig. 3c). Most species classified into the other two species rich guilds (omnivorous, and granivorous) are confirmed urban nesters (Fig. 3c). The only confirmed urban nester among the four monospecific guilds of Santiago is a strict herbivorous, the Rufous-tailed Plantcutter (Phytotoma rara) (Fig. 3c).

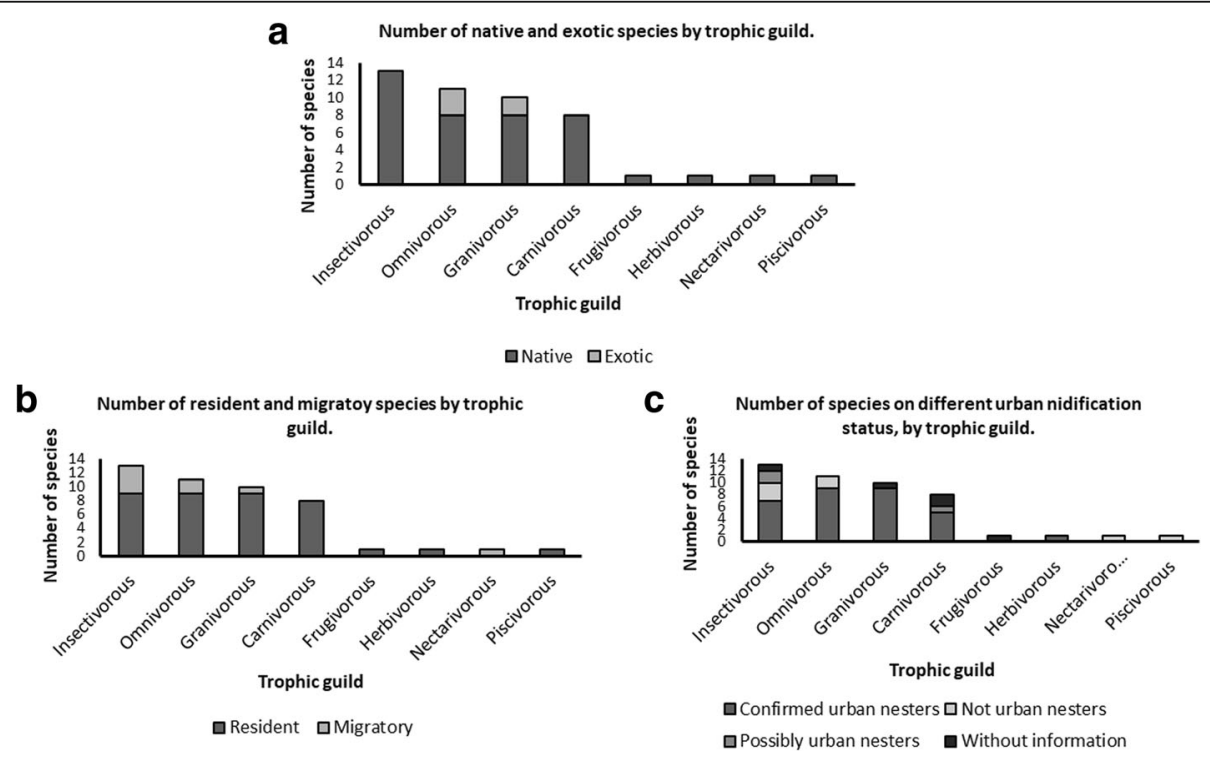

Fig. 3 Species composition inside each trophic guild. Number of (a) native and exotic (b) resident and migratory, and (c) different nesting status inside the urban perimeter of Santiago, per trophic guild 


\section{Coarse distribution of richness and abundance by functional group}

IDW interpolation of species richness for the trophic guilds (Fig. 4) shows that species richness varies from low to high relative values, where highest richness for each guild is concentrated in several focal spots, distributed across the whole urban surface of Santiago. Rarefaction curves for the complete dataset and for each of the multi-specific functional groups show a saturation pattern, meaning that differences in sample size between groups do not result in biased diversity measures, and IDW interpolation of species richness is therefore reliable (Additional file 2). Areas with species richness tending to zero for insectivorous, granivorous and omnivorous are rare (Fig. 4a, c and e). Meanwhile, the carnivorous species richness is approximately zero in most of the urban surface of the city, with some focal spots where richness ranges from low to high relative values (Fig. 4g). On the other hand, intra-guild interpolated number of individuals is homogenous, and values are relatively low for all the multi-specific guilds, with few focal spots where the number of individuals increases. Therefore, bird abundance is relatively low for all trophic guilds and over most of the urban surface of

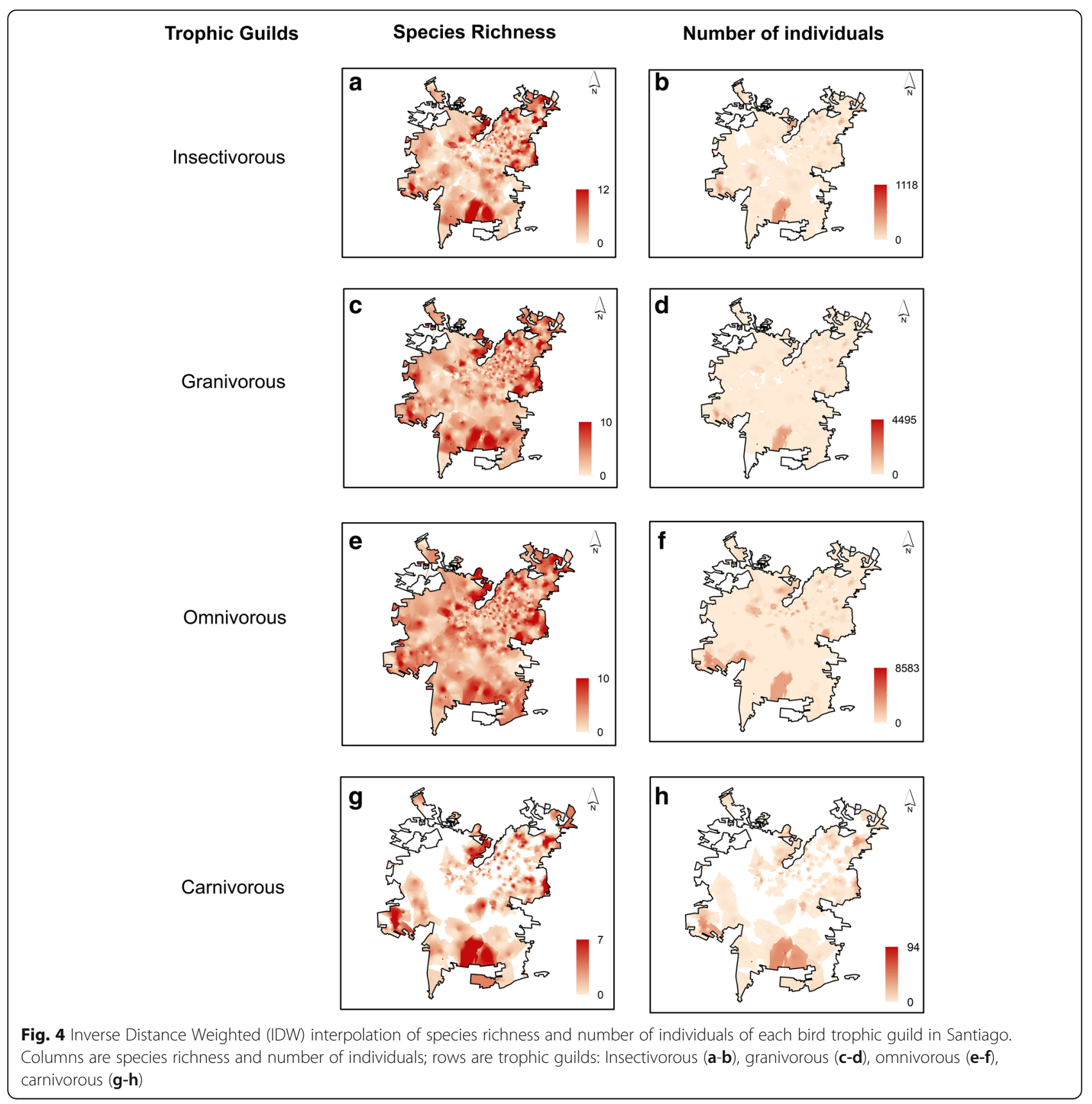


Santiago. Nevertheless, if we observe the absolute values of the number of individuals, a pattern of strong interguild differences of abundance emerges; the trophic guild with the highest relative abundance is omnivorous (reaching a maximum interpolated number of individuals over 8500, Fig. 4f). Granivorous are the next most abundant group (almost 4500 individuals in the maximum interpolated values, Fig. 4d) and insectivorous fall in the third place (more than 1100 at the maximum interpolated number of individuals, Fig. 4b). On the contrary, the carnivorous guild displays a lower number of individuals, reaching less than 100 individuals in a few spots, as the maximum interpolated value (Fig. 4h).

Concerning monospecific guilds, all of them share a lower interpolated number of individuals (compared to the four multi-specific guilds): maximum values for the number of individuals are 400 for nectarivorous, 117 for herbivorous, 25 for frugivorous and 14 for piscivorous (Additional file 3). Native species display a higher species richness and a maximum number of individuals as compared to exotic species. However, the spatial distribution of maximum values, suggest that the few exotic species present can exploit the urban surface as well as the numerous native species (several points of maximum richness in both functional groups, Fig. $5 \mathrm{a}$ and c). Nevertheless, we must take into account that the maximum number of individuals in exotic species (interpolated maximum of 2500) is lower if compared to the overall interpolated maximum of individuals in native species (interpolated maximum of 11,600) (Fig. 5b and d). In a similar way, the migratory and non-urban nester functional groups (Fig. 5g, h, k and l) show lower richness and number of individuals, as compared to resident and urban nester groups respectively (Fig. 5e, f, i and j).

Inter and intra-guild variation on the total number of individuals at the species level is high, according to eBird registers (Additional file 1, Additional file 4). Data suggest that the distribution of relative abundance inside each guild is dominated by a few species. The number of individuals inside the carnivorous guild ranges between 18 individuals of the Barn Owl (Tyto alba) to 152 and 164 individuals of American kestrels (Falco sparverius) and Harris's hawks (Parabuteo unicintus), respectively. Inside the granivorous guild, the number of individuals varies in a broad spectrum, from 30 individuals of the Mourning sierra-finch (Phrygilus fruticeti), to 1043 individuals of the Monk parakeet (Myiopsitta monachus), 1899 of the Eared dove (Zenaida auriculata) and 2132 of the Rufous-collared sparrow (Zonotrichia capensis). Meanwhile, in the omnivorous guild, values of the number of individuals by specie ranges from only 11 individuals of Franklin's gulls (Leucophaeus pipixcan) to 936 of the Chimango caracara (Milvago chimango), 1739 of the Rock dove (Columba livia) and 2614 individuals of the
Austral thrush (Turdus falcklandii). The latter is the species with the highest number of individuals registered among all the urban birds in Santiago available in e-Bird. Finally, the most species-rich guild in Santiago (insectivorous), also shares a broad spectrum for the number of individuals. These range from the low values of 14 and 16 individuals of the Patagonian forest earthcreeper (Upucerthia saturatior) and the Thorn-tailed rayadito (Aphrastura spinicauda), up to much larger values such as 634 individuals of the Southern lapwing (Vanellus chilensis) and 1124 individuals of the House wren (Troglodytes aedon).

\section{Discussion}

\section{Santiago's native and exotic species pool}

The high proportion of native species in Santiago (89\%) agrees with the high native/exotic ratio reported in other cities in the world $[4,14,15]$. However, the total species richness (46 species) is below the median of bird species in other cities of the Neotropics (above 100 species) [6]. There are urban gradient study cases which suggest that other large cities in the Neotropics share richness values comparable to Santiago, such as Mexico City [25] and Guadalajara [24] in Mexico, with 51 and 58 species respectively. In Argentina, Leveau \& Leveau [19] reported 31 bird species in the city of Mar del Plata. Other urban gradient analyses in Southern Chile suggest that bird richness values in the cities of Valdivia, Temuco and Osorno ranges between 30 to 50 species $[67,68]$. However, these cities are smaller than Santiago. Cities located in other biogeographic realms in the Southern Hemisphere also possesses higher species richness than Santiago. Particularly the Afrotropic and Indo-Malayan realms, where cities display a median richness above 200 species. Santiago's bird species richness is similar to the median number of species reported for cities in the Australasian realm (Southern Hemisphere), and in the $\mathrm{Ne}$ arctic realm (North Hemisphere) [6]. It is important to emphasize that the high native/exotic species ratio in Santiago contrasts with the observed pattern for plant species in this city, where $85 \%$ of the flora is exotic [69]. In this context, it has been proposed that urban areas with more native plant species tend to retain more native bird species [3], because the native plant species proportion [70] and volume of native vegetation [71] is positively correlated with native bird diversity in urban settlements. A note of caution must be considered here, because it has been stablished that the explanation for the uncommonly high proportion of exotic bird species (44\%) in Dunedin, New Zealand, is largely independent of plant distribution [13]. Nevertheless, we suggest an investigation of the relationship between the proportion of exotic plants and the relatively low bird species richness of Santiago. 


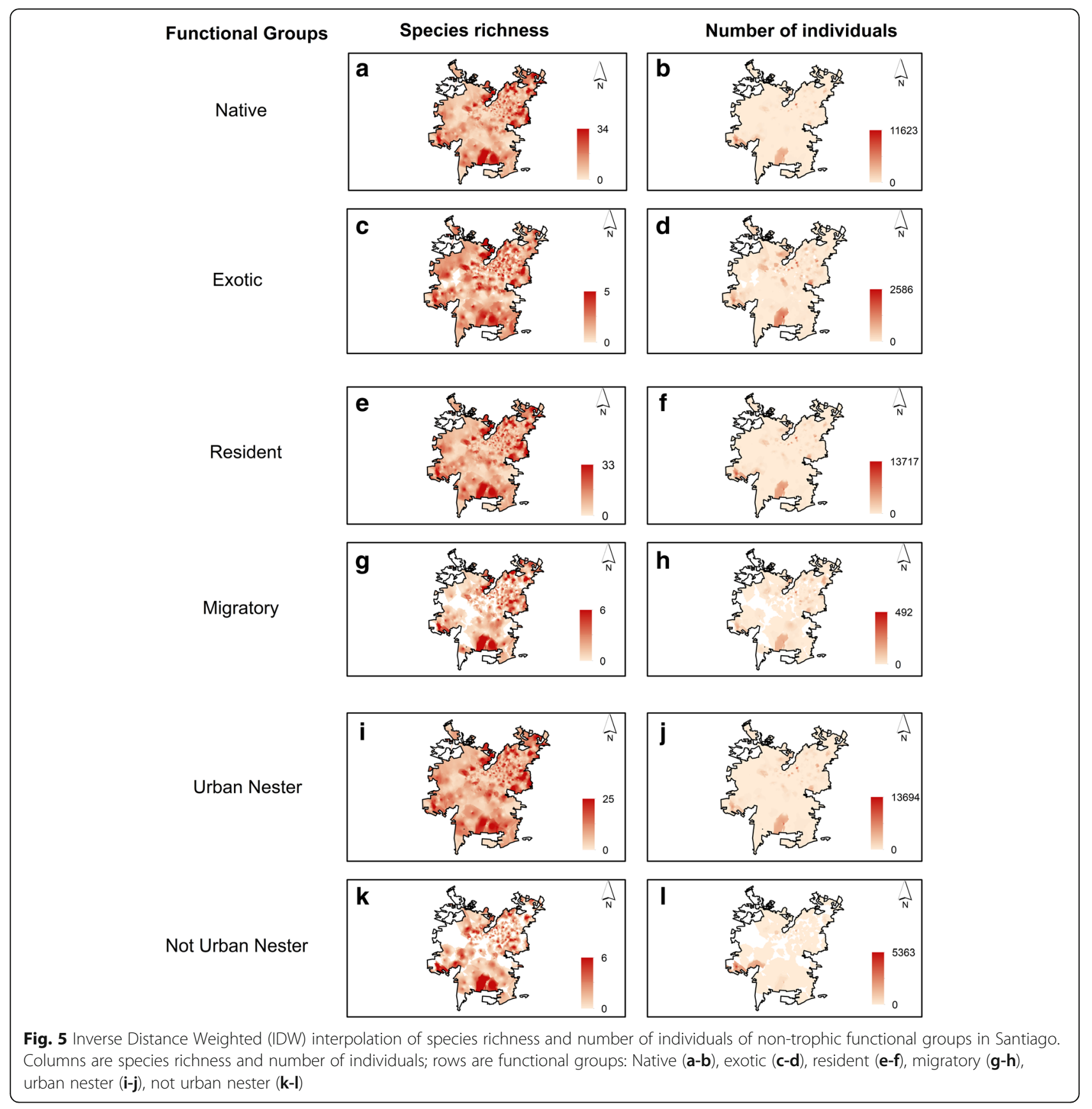

It is noticeable that, despite Santiago being located within the "Central Chile EBA", none of the 13 endemic birds of Chile [72] are represented among Santiago's urban dwellers. The absence of endemic birds in this city occurs because just three of the 13 endemic birds of Chile birds share distribution ranges that include the city of Santiago. These are cursorial species, with very specific habitat requirements for nesting and cursorial displacement, which are probably not satisfied inside urban centers (the Moustached Turca (Pteroptochos megapodius), the Whitethroated Tapaculo (Scelorchilus albicollis), and the Chilean
Tinamou -Nothoprocta perdicaria-) [55, 72]. Nevertheless, there are numerous eBird registers of these species around Santiago's urban perimeter. Therefore, we consider that the accelerated urbanization in the Central Chile EBA could be a threat to these endemic species.

Santiago's exotic bird species fraction is within the range of the low proportion of exotic bird species reported for cities in the Neotropics and other biogeographic realms [6]. It appears that all exotic species with compatible habitat requirements and enough propagule pressure around Santiago have already become successful urban dwellers. 
All this despite exotic species being a reduced fraction of this urban avifauna. The exotic bird species in this city (five species) belongs to the omnivorous and granivorous guilds. Two exotic birds share cosmopolitan distribution and their native range is located in Europe and Asia (The omnivorous Columba livia and Passer domesticus); the granivorous California quail (Callipepla californica) has its native range in North America. On the opposite, other exotics come from native distribution ranges located in South America (The omnivorous Molothrus bonariensis and the granivorous Myiopsitta monachus) [59]. Although they represents only $11 \%$ of the Santiago's urban bird assemblage, they comprise more than one half of the total exotic bird species pool (nine species) reported for the country [57]. Among Chile's invasive birds not present in Santiago (four species), there are two aquatic species whose habitats requirements are not satisfied in the city (The Muscovy Duck, Cairina moschata) and the Cattle Egret, Bubulcus ibis). The other two invasive species not considered as urban dwellers in Santiago are the Ringnecked Pheasant (Phasianus colchicus) and the Redcrested Cardinal (Paroaria coronata) [57]. Even though the latter species display omnivorous trophic habits (one of the richest trophic guilds in Santiago), they are not represented in this city. This could be explained by the fact that, despite considered invasive, their populations in Chile are scarce and they possibly do not attain enough propagule pressure to colonize large cities.

\section{The distribution of the functional groups at Santiago}

The migratory species fraction in Santiago is relatively low compared to the complete urban avifauna. This pattern raises the necessity to stablish the extension of the relevant regional bird species pool for Santiago, in order to test if urban/regional migratory species ratio is in agreement with the idea that urbanization selects against migrant bird species [20, 22, 73]. Nevertheless, an analysis about the fraction of migrant and resident bird species in different urban systems must be encouraged for conservation issues, because it has been established that migrants experience higher conservation risks than resident birds in urban environments [74]. In addition, there are examples of cities with a high proportion of bird species in some migration category, such as the South American city of La Paz, Bolivia [75]. In a similar way, we have established that the proportion of confirmed urban nesting species in Santiago is high (67\%), even though the proportion of species with uncertain $(7 \%)$ or no information $(11 \%)$ about urban nesting is considerable. Either way, more complete and detailed information about Santiago's nesting patterns is strongly needed in order to asses if some nesting strategy is favored in this city, as cavity-nesters or above-ground nesters do in other cities in the world $[20,76]$.
The highest species richness among Santiago's trophic guilds occurs in the insectivorous, followed by omnivorous, granivorous, and carnivorous. By considering the number of registered individuals as a proxy of abundance relationships, it is possible to hypothesize that Santiago's avifauna is numerically dominated by omnivorous, followed by granivorous and insectivorous in third place. The spatial distribution of the interpolated species richness and number of individuals, suggest that species of the previously mentioned guilds are able to exploit a larger extent of urban habitats than the carnivorous guild, which display large areas where both the interpolated species richness and number of individuals tends to zero. They also reach a maximum number of individuals, which is several magnitude orders higher than those observed for the carnivorous guild. This pattern agrees with evidence from cities in several countries across the world (e.g. Finland, Mexico, Venezuela, Canada and France). which suggest that highly urbanized habitats can select for omnivorous species [12, 15, 21, 25, 73], which can exploit an additional food supply associated to human activities, especially in cities where winter imposes a reduced food supply and a restrictive energetic budget for birds. Singapore is a city located in a tropical area, where winter food supplies and energetic budget is non-restrictive. Contrary to the former examples, Singapore's highly urbanized areas can select for granivorous, while omnivorous are not favored in the extremes of the urban gradient [14]. The same pattern of selection for granivorous in highly urbanized habitats has been reported in a study conducted in three different ecoregions in the United States [20]. Santiago is in a Mediterranean - type area, where the rainy season falls in winter, with moderate temperatures. This climatic setup is comparable to that of the city of Jerusalem, where omnivorous have been found to be the dominant trophic guild in the downtown area [22].

Insectivorous birds are considered to be negatively affected by the degree of urbanization, and there are numerous examples of low representation and selection against species of this guild in several cities [3, 12, 15, 20-22]. Nevertheless, there is growing evidence of high insectivorous richness coming from cities located in the Neotropics [19, 23, 25, 75, 77] and Indo-Malayan realms $[14,78]$. In sum, this evidence suggests that urban environments outside the Palearctic and Nearctic realms can sustain a high insectivorous richness. Santiago's distribution of species richness and number of individuals shows that insectivorous birds are able to exploit habitats across most of the urban surface, being the guild with the highest species richness, and the third most abundant among Santiago's trophic guilds. The mechanisms that potentially explain the high insectivorous richness and abundance should be investigated in order to provide more evidence about the importance of the 
insectivorous guild in cities of the Neotropical realm. In this context, it has been proposed that insectivorous birds in Mexico City are the dominant group, but they are highly represented only in parks, large gardens, and other areas where trees and vegetation are abundant [25]. Supporting this argument, de Toledo et al. [77] propose that urban environments can, in fact, provide a large food supply for insectivorous birds, because arthropods are often a diverse and abundant group in urban environments. Therefore, the effects of vegetated areas and degree of prey availability on the distribution of insectivorous birds should be evaluated for Santiago.

Altogether, carnivorous distribution of interpolated species richness, and absolute number of individuals, suggest that this guild is the least successful (among the four proposed multispecific guilds) in exploiting the urban environment of Santiago. The carnivorous guild appears to be restricted to a few spots were species richness is relatively high, but abundance seems to be low, compared to omnivorous, granivorous and insectivorous. The fact that carnivorous are represented by several species in Santiago, despite being geographically and numerically restricted, is in agreement with the explanation proposed by Chace \& Walsh [3], which stablished that carnivorous as raptors may possess home ranges larger than city boundaries, not requiring to satisfy all their ecological needs inside the city. Several carnivorous species registered in Santiago are raptors, whose nesting pattern and trophic habits inside the city are unknown. Therefore, their observed urban distribution could be a consequence of a broad home range, which allows them satisfy -at least partially- their ecological needs outside the boundaries of Santiago.

Overall, we hypothesize that food availability for birds in the urban habitats of Santiago allow the city to sustain a high richness and abundance of omnivorous (which can benefit from anthropogenic food), granivorous and insectivorous (which are likely to find their alimentary items across the parks and open spaces within Santiago). Other guilds display trophic requirements that are hypothetically more restrictive in Santiago, such as nectarivorous, frugivorous, herbivorous and piscivorous. These guilds are mono-specific and reach lower numbers, and show a reduced and patchy geographic coverage (Additional file 3), as compared to the multi-specific guilds which numerically dominate the city. Considering the complete avifauna, the spatial location of high richness and abundance spots is distributed across Santiago's urban surface. No obvious diversity gradient appears, despite the fact that registers are denser in the central and eastern parts of the city, situated between the main rives of Santiago (Fig. 1).

In consequence, what challenges are emerging from this promising system for the urban avifauna? Twenty two percent of Santiago's bird species have an unknown or uncertain nesting status; this lack of information is critical, because seven of the 10 species classified into the "probable" or "without information" nesting categories belong to the insectivorous and carnivorous guilds, which we propose as interesting traits of Santiago's avifauna. Therefore, more detailed information regarding nesting categories for urban birds, and descriptions about urban nesting patterns, should be encouraged at this city. For the same reasons, dietary studies inside the urban perimeter of Santiago must be considered a priority, because current trophic categorization of Santiago's birds comes from evidence that has not been evaluated inside urban habitats.

Finally, the use of the citizen based platform eBird has revealed the coarse structure of Santiago's functional groups, and suggested the geographic distribution patterns and overall abundance relationships. As a corollary, we sustain that the combined efforts of citizens and researchers has positioned eBird as a useful tool to reveal the general distribution of urban avifauna, and to potentially reveal patterns at a geographical scale which would be otherwise prohibitive, in a traditional sampling approach. This information framework encourages its use to continue enhancing the use of this tool in ornithological research. Simultaneously, we suggest further research projects about the city's avifauna, in several topics such as the characterization of the habitats experienced by Santiago's urban birds inside the city, the degree of urbanization, the vegetation coverage, and the food availability for different trophic guilds.

\section{Conclusion}

We conclude that the avifauna of Santiago shows a relatively low species richness as compared to other cities in the Neotropics. Santiago's bird biodiversity is composed mainly of native, resident, non-threatened species that breed inside the city. There are functional groups that inhabit a large portion of Santiago's urban surface, reaching relatively high values of richness and abundance. Among these functional groups are the native, urban nesters and resident species. Although exotics possess low species richness, this group is highly abundant and inhabit almost the complete urban surface of the city. The dominant trophic guilds in terms of species richness and abundance are omnivorous and granivorous; insectivorous are the third most abundant trophic guild, with the highest species richness. The functional groups with lower species richness are usually less abundant, and display more reduced and patchy distributions in Santiago, probably because of low availability of suitable habitats and/or restricted food supply (migrants, carnivorous, nectarivorous, herbivorous, frugivorous and piscivorous). The high insectivorous richness, reported 
in the large South American city of Santiago, brings evidence to postulate a pattern of high species richness of this guild in cities from the Neotropics (and possibly also the Indo-Malayan) realm. The fact that even the exotic bird species pool in this city possess an important fraction of South American species emphasizes the need to close the information gap about urban bird ecology and biodiversity in the underrepresented South Hemisphere. This research agenda will help to improve the understanding of ecology and biodiversity of southern urban avifauna, while diminishing the information gap about urban birds in different biogeographical realms.

\section{Additional files}

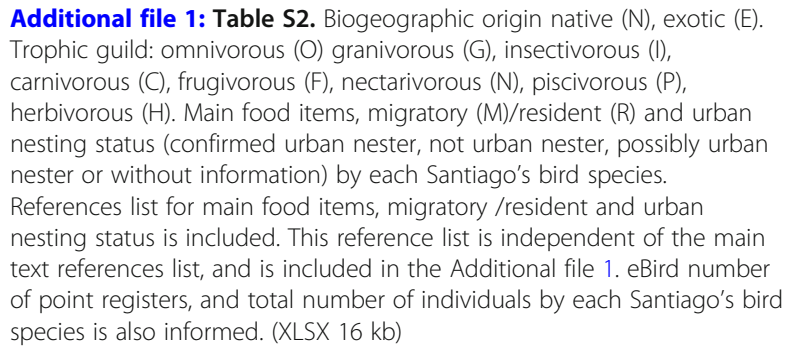

Additional file 2: Figure S8. Rarefaction curves for each functional group, multi-specific trophic guilds, and the complete urban species pool. A) Native, B) Exotic, C) Resident, D) Migratory, E) Urban nesters, F) Not urban nesters G) Insectivorous, H) Omnivorous, I) Granivorous, J) Carnivorous, K) All urban birds. (TIFF $287 \mathrm{~kb}$ )

Additional file 3: Figure S6. Summary of point registers and Inverse Distance Weighted (IDW) interpolation for the number of individuals of monospecific trophic guilds in Santiago. Columns are point registers and number of individuals; rows are trophic guilds: Nectarivorous (A-B), frugivorous (C-D), herbivorous (E-F), piscivorous (G-H). (TIFF $394466 \mathrm{~kb}$ )

Additional file 4: Figure S7. Distribution of the number of point registers and total number of individuals by species according to eBird, for Santiago's birds between years 2009-2016. (TIFF $106 \mathrm{~kb}$ )

\section{Abbreviations \\ C: Carnivorous species; E: Exotic; EBA: Endemic bird area; F: Frugivorous species; G: Granivorous species; H: Herbivorous species; I: Insectivorous species; IDW: Inverse distance weighted method; IUCN: International Union for the Conservation of Nature; M: Migratory; N: Native; N: Nectarivorous species; O: Omnivorous species; P: Piscivorous species; R: Resident}

\section{Acknowledgements}

We gratefully acknowledge to Fernando Medrano, from the "Red de Observadores de Aves y Vida Silvestre de Chile" (ROC), who kindly provided bird registers in central Chile, from the eBird Chile database, and the access to bird registers in central Chile granted by the free access database eBird.org (Cornell Lab of Ornithology). We also acknowledge the technical support on geographic information systems provided by Maximiliano Bolados. Finally, we gratefully acknowledge to Juan Fernando Hernández, who kindly reviewed an advanced version of this work.

\section{Funding}

PGT acknowledge the financial support of "Proyectos Basales USA1555 USACH-MECESUP (№23/2017 Código 1555.48)".

SAC gratefully acknowledge the support of the Center for the Development of Nanoscience and Nanotechnology, CEDENNA FB0807 - Line 6, and "Proyectos Basales USA1555 USACH-MECESUP (№23/2017 Código 1555.48)".

\section{Availability of data and materials}

This work was conducted under a signed agreement with the "Red de Observadores de Aves y Vida Silvestre de Chile" (ROC), restricting the use of eBird Chilean data for research purposes only.

\section{Authors' contributions}

MIA contributed with data collection, preparation and review; MIA also contributed to the manuscript edition. SAC and PGT conceived the idea, while SAC contributed substantial resources for the research, and made significant contributions editing the paper. PGT conducted the research, edited and analyzed the data, and wrote the draft manuscript. All authors read and approved the final manuscript.

\section{Ethics approval and consent to participate}

Not applicable.

\section{Consent for publication}

Not applicable.

\section{Competing interests}

The authors declare that they have no competing interests.

\section{Publisher's Note}

Springer Nature remains neutral with regard to jurisdictional claims in published maps and institutional affiliations.

\section{Author details}

'Laboratorio de Ecología y Biodiversidad, Departamento de Biología, Universidad de Santiago de Chile, Casilla 40, Correo 33, Santiago. Av. Lib. B. O'Higgins, 3363 Santiago, Chile. ${ }^{2}$ Departamento de Química de los Materiales, Facultad de Química y Biología, Universidad de Santiago de Chile, Av. Libertador B. O'Higgins, 3363 Santiago, Chile. ${ }^{3}$ Centro para el Desarrollo de la Nanociencia y Nanotecnología, CEDENNA, 917-0124, Av. Lib. B. O’Higgins, 3363 Santiago, Chile.

Received: 29 November 2017 Accepted: 16 March 2018 Published online: 27 March 2018

\section{References}

1. Mckinney ML. Urbanization, biodiversity, and conservation. Bioscience. 2002; 52:883-90.

2. Seto KC, Güneralp B, Hutyra LR. Global forecasts of urban expansion to 2030 and direct impacts on biodiversity and carbon pools. Proc Natl Acad Sci U S A. 2012;109:16083-8. https://doi.org/10.1073/pnas.1211658109.

3. Chace JF, Walsh JJ. Urban effects on native avifauna: a review. Landsc Urban Plan. 2006:74:46-69. https://doi.org/10.1016/j.landurbplan.2004.08.007.

4. Clergeau P, Croci S, Jokimäki J, Kaisanlahti-Jokimäki ML, Dinetti M. Avifauna homogenisation by urbanisation: analysis at different European latitudes. Biol Conserv. 2006;127:336-44. https://doi.org/10.1016/j.biocon.2005.06.035.

5. Marzluff J, Bowman R, Donnelly R. Avian ecology and conservation in an urbanizing world. Boston: Kluwer Academic Publishers; 2001.

6. Aronson MFJ, La Sorte FA, Nilon CH, Katti M, Goddard MA, Lepczyk CA, Warren PS, Williams NSG, Cilliers S, Clarkson B, Dobbs C, Dolan R, Hedblom M, Klotz S, Kooijmans JL, Kühn I, Macgregor-Fors I, McDonnell M, Mörtberg U, Pysek P, Siebert S, Sushinsky J, Werner P, Winter M. A global analysis of the impacts of urbanization on bird and plant diversity reveals key anthropogenic drivers. Proceedings Biol Sci. 2014;281:20133330. https://doi. org/10.1098/rspb.2013.3330.

7. Marzluff JM (2016) A decadal review of urban ornithology and a prospectus for the future. Ibis (Lond 1859) 159:http://doi.wiley.com/10.1111/ibi.12430. doi: https://doi.org/10.1111/ibi.12430.

8. Ortega-Álvarez R, MacGregor-Fors I. Dusting-off the file: a review of knowledge on urban ornithology in Latin America. Landsc Urban Plan. 2011;101:1-10. https://doi.org/10.1016/j.landurbplan.2010.12.020.

9. Young KM, Daniels CB, Johnston G. Species of street tree is important for southern hemisphere bird trophic guilds. Austral Ecol. 2007;32:541-50. https://doi.org/10.1111/j.1442-9993.2007.01726.x.

10. Morrone J. Biogeographical regionalisation of the world : a reappraisal. Aust Syst Bot. 2015;28:81-90. https://doi.org/10.1071/SB14042. 
11. Stattersfield A, Crosby M, Long A, Wege D. Endemic bird areas of the world: priorities for biodiversity conservation. Cambridge: BirdLife International; 1998.

12. Clergeau P, Savard JPL, Mennechez G, Falardeau G. Bird abundance and diversity along an urban-rural gradient: a comparative study between two cities on different continents. Condor. 1998;100:413-25. https://doi.org/10. 2307/1369707.

13. van Heezik Y, Smyth A, Mathieu R. Diversity of native and exotic birds across an urban gradient in a New Zealand city. Landsc Urban Plan. 2008;87:22332. https://doi.org/10.1016/j.landurbplan.2008.06.004

14. Lim HC, Sodhi NS. Responses of avian guilds to urbanisation in a tropical city. Landsc Urban Plan. 2004;66:199-215. https://doi.org/10.1016/S01692046(03)00111-7.

15. Sanz V, Caula S. Assessing bird assemblages along an urban gradient in a Caribbean island ( Margarita, Venezuela ). Urban Ecosyst. 2014; https://doi. org/10.1007/s11252-014-0426-4

16. Clergeau P, Jokimäki J, Savard JPL. Are urban bird communities influenced by the bird diversity of adjacent landscapes? J Appl Ecol. 2001;38:1122-34. https://doi.org/10.1046/j.1365-2664.2001.00666.x.

17. McKinney ML. Urbanization as a major cause of biotic homogenization. Biol Conserv. 2006;127:247-60. https://doi.org/10.1016/j.biocon.2005.09.005.

18. Lancaster RK, Rees WE. Bird communities and the structure of urban habitats. Can J Zool. 1979;57:2358-68. https://doi.org/10.1139/z79-307.

19. Leveau LM, Leveau CM. Comunidades de aves en un gradiente urbano de la ciudad de Mar del Plata, Argentina. Hornero. 2004;19:13-21.

20. Blair RB, Johnson EM. Suburban habitats and their role for birds in the urban-rural habitat network: points of local invasion and extinction? Landsc Ecol. 2008;23:1157-69. https://doi.org/10.1007/s10980-008-9267-y.

21. Jokimäki J, Suhonen J. Distribution and habitat selection of wintering birds in urban environments. Landsc Urban Plan. 1998;39:253-63. https://doi.org/ 10.1016/S0169-2046(97)00089-3

22. Kark S, Iwaniuk A, Schalimtzek A, Banker E. Living in the city: can anyone become an "urban exploiter"? J Biogeogr. 2007;34:638-51. https://doi.org/10. 1111/j.1365-2699.2006.01638.x.

23. Carbó-Ramírez P, Zuria I. Landscape and urban planning the value of small urban greenspaces for birds in a Mexican city. Landsc Urban Plann. 2011; 100:213-22. https://doi.org/10.1016/j.landurbplan.2010.12.008.

24. Macgregor-fors I. Relation between habitat attributes and bird richness in a western Mexico suburb. Landsc Urban Plan. 2008;84:92-8. https://doi.org/10. 1016/j.landurbplan.2007.06.010

25. Ortega-Álvarez R, MacGregor-Fors I. Living in the big city: effects of urban land-use on bird community structure, diversity, and composition. Landsc Urban Plan. 2009;90:189-95. https://doi.org/10. 1016/j.landurbplan.2008.11.003.

26. Reynaud P, Thioulouse J. Identification of birds as biological markers along a neotropical urban-rural gradient (cayenne, French Guiana), using co-inertia analysis. J Environ Manag. 2000;59:121-40. https://doi.org/10.1006/jema. 2000.0338.

27. Jokimäki J, Kaisanlahti-Jokimäki M-L, Sorace A, Fernández-Juricic E, Rodríguez-Prieto I, Jimenez MD. Evaluation of the "' safe nesting zone "' hypothesis across an urban gradient : a multi-scale study. Ecography (Cop). 2005;28:59-70

28. Instituto Nacional de Estadísticas (INE) (2005) Chile: Ciudades, pueblos, aldeas y caseríos. 300.

29. Instituto Nacional de Estadísticas (INE). División Político-administrativa y censal 2007. Santiago: Gobierno de Chile; 2008.

30. Myers N, Mittermeier RA, Mittermeier CG, Fonseca GAB, Kent J. Biodiversity hotspots for conservation priorities. Nature. 2000;403:853-8.

31. BirdLife International (2017) Endemic bird areas factsheet: Central Chile. http://datazone.birdlife.org/eba/factsheet/62. Accessed 17 Jul 2017.

32. Celis-Diez J, Muñoz C, Abades S, Marquet P, Armesto J. Biocultural homogenization in urban settings: public knowledge of birds in City parks of Santiago, Chile. Sustainability. 2017;9:485. https://doi.org/10.3390/ su9040485.

33. Díaz I, Armesto J. La conservación de las aves silvestres en ambientes urbanos de Santiago. Rev Ambient y Desarro. 2003;19:31-8.

34. Egli G, Aguirre J. Aves de Santiago. Santiago: UNORCH; 2000.

35. Estades C. Aves y vegetación urbana: El caso de las plazas. Boletín Chil Ornitol. 1995;2:7-13.

36. Mella JE, Loutit A. Ecología comunitaria y reproductiva de aves en cerros islas y parques de Santiago. Boletín Chil Ornitol. 2007;13:13-27.
37. Varela S. Calidad de la vegetación urbana como hábitat para aves. El caso de Santiago de Chile: Universidad de Chile; 2003.

38. Sullivan BL, Wood MJ, Liff MJ, Bonney RE, Fink D, Kelling S. eBird: a citizen-based bird observation network in the biological sciences. Biol Conserv. 2009;142:2282-92.

39. United Nations (2015) World urbanization prospects: the 2014 revision, (ST/ ESA/SER.A/366).

40. National_Congress_Library_of_Chile (2017) Vector maps [online]. Retrieved from: <https://www.bcn.cl/siit/mapas_vectoriales/. Consulted on: October 10, 2017.

41. Morrone JJ. Biogeographic areas and transition zones of Latin America and the Caribbean islands based on panbiogeographic and cladistic analyses of the entomofauna. Annu Rev Entomol. 2006;51:467-94. https://doi.org/10. 1146/annurev.ento.50.071803.130447.

42. BirdLife International (2017) Endemic bird areas: Chile. http://datazone. birdlife.org/eba/results?cty=43\&sn=\&fc=\&cri=. Accessed $17 \mathrm{Jul} 2017$

43. eBird. eBird: an online database of bird distribution and abundance [web application]. Ithaca: eBird; 2012. Available: http://www.ebird.org. Accessed: February 2017

44. Callaghan CT, Gawlik DE. Efficacy of eBird data as an aid in conservation planning and monitoring. J F Ornithol. 2015;86:298-304. https://doi.org/10. 1111/jofo.12121.

45. Clark CJ. eBird records show substantial growth of the Allen's hummingbird (Selasphorus sasin sedentarius ) population in urban Southern California. Condor. 2017;119:122-30. https://doi.org/10.1650/CONDOR-16-153.1.

46. Fournier AMV, Sullivan AR, Bump JK, Perkins M, Shieldcastle MC, King SL. Combining citizen science species distribution models and stable isotopes reveals migratory connectivity in the secretive Virginia rail. J Appl Ecol. 2017 54:618-27. https://doi.org/10.1111/1365-2664.12723.

47. Kelling S, Gerbracht J, Fink D, Lagoze C, Damoulas T, Gomes C. eBird: a human / computer learning network for biodiversity conservation and research. In: Proceedings of the twenty-fourth innovative Appications of artificial intelligence conference; 2012. p. 2229-36.

48. Kolstoe S, Cameron TA. The non-market value of birding sites and the marginal value of additional species: biodiversity in a random utility model of site choice by eBird members. Ecol Econ. 2017;137:1-12. https://doi.org/ 10.1016/j.ecolecon.2017.02.013.

49. Lagoze C. eBird: curating citizen science data for use by diverse communities. Int J Digit Curation. 2014;9:71-82. https://doi.org/10.2218/ijdc.v9i1.302.

50. La Sorte FA, Fink D, Hochachka WM, Kelling S. Convergence of broad-scale migration strategies in terrestrial birds. Proc R Soc B. 2016;283:20152588. https://doi.org/10.1098/rspb.2015.2588.

51. Suyundikov A, Symanzik J. A graphical assessment and spatial clustering of the Deepwater horizon oil spill impact on laughing gulls. Environ Ecol Stat. 2017;24:297-316. https://doi.org/10.1007/s10651-017-0371-5.

52. Walker J, Taylor PD. Using eBird data to model population change of migratory bird species. Avian Conserv Ecol. 2017;12:4. https://doi.org/10. 5751/ACE-00960-120104

53. Jaksic FM, Pavez EF, Jimenez JE, Torres-Mura JC. The conservation status of raptors in the metropolitan region, Chile. J Raptor Res. 2001:151-8.

54. Jaramillo A, Barros R (2017) Species lists of birds for south American countries and territories: Chile. http://www.museum.lsu.edu/ Remsen/ SACCCountryLists.htm. Accessed 3 Mar 2017.

55. Jaramillo A. Aves de Chile. 1st ed. Barcelona: Ediciones Lynx; 2005.

56. The Cornell lab of Ornithology. Glossary. In: Lovett IJ, Fitzpatrick JW, editors. Handbook of bird biology. 3rd ed. Ithaca: The Cornell lab of Ornithology; 2016. p. 641.

57. Ray CA, Escobedo-Echeverría V, Castro SA, Jaksic FM. Catálogo de la flora y fauna invasora. In: Jaksic FM, Morales SAC, editors. Invasiones Biológicas en Chile. Santiago: Ediciones Universidad Católica de Chile; 2014. p. 491-509.

58. Richardson DM, Pyšek P, Rejmánek M, Barbour MG, Dane Panetta F, West CJ. Naturalization and invasion of alien plants: concepts and definitions. Divers Distrib. 2000;6:93-107. https://doi.org/10.1046/j.14724642.2000.00083.x

59. IUCN (2017) The IUCN Red List of Threatened Species. Version 2016-3. $<$ www.iucnredlist.org>. Downloaded on 24 February 2017.

60. Jaksic FM, Feinsinger P. Bird assemblages in temperate forests of north and South America: a comparison of diversity, dynamics, guild structure, and resource use.L. Rev Chil Hist Nat. 1991:64:491-510.

61. ESRI (2011) ArcGIS desktop: release 10.3. 
62. Abdi A, Nandipati A. Bird diversity modeling using Geostatistics and GIS. In: 12th AGILE international conference on geographic information science, 2-5 June 2009. Hannover: Universitat Hannover; 2009. p. 1-20.

63. Pereira GA, Araújo HFP, Azevedo-Júnior M (2016) Distribution and conservation of three important bird groups of the Atlantic Forest in northEast Brazil. Brazilian J Biol 76:1004-1020. doi: https://doi.org/10.1590/15196984.06815

64. Roberts EA, Sheley RL, Lawrence RL. Using sampling and inverse distance weighted modeling for mapping invasive plants. West North Am Nat. 2004; 64:312-23.

65. Zador SG, Parrish JK, Punt AE, Burke JL, Fitzgerald SM. Determining spatial and temporal overlap of an endangered seabird with a large commercial trawl fishery. Endanger Species Res. 2008;5:103-15. https://doi.org/10.3354/ esr00152.

66. Oksanen J, Blanchet FG, Friendly $M$, Kindt R, Legendre $P, M c G l i n n ~ D$, Minchin PR, O'Hara RB, Simpson GL, Solymos P, Henry M, Stevens H, Szoecs E, Wagner H (2018) Vegan: community ecology package.

67. Silva CP, García CE, Estay SA, Barbosa O, Chapman MG. Bird richness and abundance in response to urban form in a Latin American City: Valdivia, Chile as a case study. PLoS One. 2015;10:1-16. https://doi.org/10.1371/ journal.pone.0138120.

68. Silva CP, Sepúlveda RD, Barbosa O. Nonrandom filtering effect on birds: species and guilds response to urbanization. Ecol Evol. 2016;6:3711-20. https://doi.org/10.1002/ece3.2144.

69. Figueroa JA, Teillier S, Guerrero Leiva N, Ray-Bobadilla C, Rivano S, Saavedra D, Castro SA. Vascular flora in public spaces of Santiago, Chile. Gayana Botánica. 2016;73:85-103.

70. Emlen JT. An urban bird Community in Tucson, Arizona: derivation, structure, regulation. Condor. 1974;76:184-97. https://doi.org/10.2307/ 1366729.

71. Mills SG, Dunning JBJ, Bates JM. Effects of urbanization on breeding bird community structure in Southwestern Desert habitats. Condor. 1989; 91:416-28. https://doi.org/10.2307/1368320.

72. BirdLife International (2017) Single country endemics: Chile. http://datazone. birdlife.org/species $/$ results?cty $=43 \&$ fam $=0 \& g e n=0 \& s t s c e=Y \& h d n$ Action $=$ ADV_SEARCH. Accessed 17 Jul 2017.

73. Blair RB. Land use and avian species diversity along an urban gradient. Ecol Appl. 1996;6:506-19. https://doi.org/10.2307/2269387.

74. MacGregor-Fors I, Morales-Pérez L, Schondube JE. Migrating to the City: responses of Neotropical migrant bird communities to urbanization. Condor. 2010;112:711-7. https://doi.org/10.1525/cond.2010.100062.

75. Martínez O, Olivera M, Quiroga C. Avifauna evaluation of the La Paz City, Bolivia. Rev perbiol. 2010;17:197-206.

76. Jokimäki J, Huhta E. Artificial nest predation and abundance of birds along an urban gradient. Condor. 2000;102:838-47.

77. de Toledo MCB, Donatelli RJ, Batista GT. Relation between green spaces and bird community structure in an urban area in Southeast Brazil. Urban Ecosyst. 2012;15:111-31. https://doi.org/10.1007/s11252-011-0195-2.

78. Yu T, Guo Y. Effects of urbanization on bird species richness and community composition. Pak J Zool. 2013:45:59-69.

\section{Submit your next manuscript to BioMed Central and we will help you at every step:}

- We accept pre-submission inquiries

- Our selector tool helps you to find the most relevant journal

- We provide round the clock customer support

- Convenient online submission

- Thorough peer review

- Inclusion in PubMed and all major indexing services

- Maximum visibility for your research

Submit your manuscript at www.biomedcentral.com/submit
Biomed Central 